\title{
The Effect of Organizational Culture, Pedagogic Competency, And Motivation of Working to Organizational Commitment Teacher SMK in District Dairi
}

\author{
Johannes Sohirimon Lumbanbatu \\ St. Bonaventura KAM, Medan Delitua \\ Babby Hasmayni Universitas Medan Area Medan, Indonesia \\ Paningkat Siburian Professor at Universitas Negeri Medan
}

\begin{abstract}
This study examines the direct influence of organizational culture, pedagogic competence, and work motivation towards the organizational commitment of SMK teachers in Dairi Regency. The population of this research is teachers of Stated/Private SMK in Dairi Regency amounted to 481 people. Using a stratified proportional random sampling technique, the Cochran formula obtained 208 people. The research instrument is a questionnaire with Likert scale for organizational culture, work motivation, and organizational commitment. While for pedagogic competence variable use instrument test. Research data were analyzed by using path analysis technique. The results of the analysis show: X1 to $\mathrm{X} 3$ of $0.377, \mathrm{X} 1$ to $\mathrm{X} 4$ of $0.368, \mathrm{X} 2$ to $\mathrm{X} 3$ of $0.161, \mathrm{X} 2$ to $\mathrm{X} 4$ of 0.415 , and $\mathrm{X} 3$ toxic $\mathrm{X} 4$ of 0.406 . Thus, the results of this study can be concluded that: organizational culture, pedagogic competence, and work motivation directly influence the commitment of teacher's organization Stated/Private SMK in Dairi Regency
\end{abstract}

Keywords : Organizational Culture, Pedagogic Competence, Work Motivation, Organizational Commitment

\section{Introduction}

Problems relating to teachers are still a serious problem and very need to find a way out. Teachers as one of the leading components in the learning process still has various limitations. Weaknesses that have subsequent impact on the ability to carry out the process of learning and coaching to students.

Teaching, educating, guiding and training activities that are the main task of teachers are still not implemented optimally at all levels and units of education. This is due to the lack of teachers' ability in the field of duties, the low motivation in performing the tasks, and the lack of supervision (supervision) conducted by the principal and supervisors in the educational unit and the low loyalty (commitment) of teachers to the institution in which it performs its duties. Factually there are many more factors that have not implemented the task of teachers, as has been specified in the law. All of the mentioned factors strongly influence the teacher's commitment in performing his duties at educational institutions/ schools.

Given the importance and strategic duties and role of teachers in the learning activities in schools, it is appropriate that the problems associated with the teacher is looked for way out / solving seriously. Thus it can be said that the teacher as one of the important and leading elements in the multi-role learning process, is not limited only as a teacher who transfer the knowledge to the students, but also as a guide that encourages potential, develops alternatives, and mobilizes students in learning. This means that teachers have complex tasks and responsibilities towards the achievement of educational goals, where teachers are not only required to master the science to be taught to students and have a set of knowledge and technical skills of teaching, but teachers are also required to display a personality capable of being role model for his students at school.

Given the sheer weight of tasks that teachers have to do at school, it is appropriate that teachers get many things that can arouse their spirits in performing their tasks, and understand what they do. This is important, because a teacher will generate a good organizational commitment if they have good competence and have high work motivation, and supported by a conducive organizational culture in the workplace. 
Organizational commitment (organizational commitment) is one of the behaviors in the organization that many discussed and researched, whether as a dependent variable, independent variables, and mediator variables. This is partly due to the organization requires employees who have high organizational commitment for the organization to continue to survive and improve the services and products it produces. Employees with high organizational commitment are more stable and more productive employees and ultimately more profitable for the organization. Organizational commitment is concerned with the high desire to share and sacrifice for the organization.

Related to organizational commitment in SMK Dairi Regency can be stated still in low category. This is based on observations in December 2016 which the author did in several vocational schools. Some facts can be expressed, among others: (1) the number and percentage of teacher attendance both at the time of teaching and mentoring to students is still small. (2) Teacher profession with main tasks of teaching, educating, guiding and training has not been the main employee. There are still many teachers who do side jobs with other jobs outside of teaching hours.

Some facts that indicate the low commitment of SMK teachers organization in Dairi Regency is motivated by the environment that is still less support towards the establishment of positive organizational commitment. The teacher's background is also a determinant factor causing low teacher organizational commitment. This is certainly contrary to the certification allowance that has been accepted by most SMK teachers in thearea.

If traced in depth, there are at least three important factors that affect the emergence of work motivation, namely; (1) individual wants and needs (2) goals and perceptions of individuals or groups of organizations, (3) ways to realize those needs / goals.

Based on the facts found in the field and the results of research related to the organizational commitment of SMK teachers has been able to identify the factors that are suspected to have a positive and significant relationship. Given the factors that affect the organization's commitment is important for SMK teachers. Because SMK is the level that bridges basic education and higher education whose graduates are at the crossroads to higher education or to the world of work. So that learning activities undertaken in vocational schools should be able to accommodate the various needs and interests of students, especially students who will enter the workforce.

The implication is, SMK must be able to provide environment and learning activities that can equip students in accordance with the required capabilities, so as to enter the increasingly competitive world of work. This challenge will be a measure for teachers in the performance of their duties. Organizational culture factors, pedagogic competence, and work motivation are expected to influence the organizational commitment of teachers in SMK Dairi District.

\section{LITERATURE}

Commitment is a condition that cannot be forced and a condition that must be developed through feelings of involvement (Stout \& Alan, 1995: 21). Furthermore Steers Porter \& Lyman (1991: 85), emphasizes that commitment is a process in which someone is psychologically involved with his work.

As explained by Odiorme (1990: 87), commitment is a psychological condition that shows a serious will to take action or carry out special work, and this is internalized within. Commitment in a person will make someone have a great desire to be consistent in 
acting, both in making their own decisions or in dealing with others. So that the pressure that comes from within and from others does not make it change the decision and direction of action.

School organizations can be regarded as a social system that pursues specific objectives, whose members have the role of providing the best service possible to achieve these goals. The service of the members of the organization requires their commitment, namely the willingness to side with the organization, so that the organization can achieve its goals.

To reinforce the existence of members in an organization Stoner at.al (1995: 19), provide a definition of the organization as a pattern of cooperation between two or more people who are bound in a structured way to achieve one or a set of specific goals. Purpose is a fundamental element in the organization, so that without a goal, there is no reason for an organization to exist. This goal is something that must be achieved by the organization, including by its members.

Furthermore Schatz \& Schatz (1986: 76), states that the core of commitment is trust and intimacy. Trust is proof of commitment, without trust commitment will never exist. Trust is the fruit of commitment. The organization will give trust to its members because of the commitment of members to the organization. The commitment of members to the organization and the trust of the organization to the members makes the two relations harmonious, there is intimacy between members and members and between members and organizations. Commitment includes its orientation towards the organization in the context of loyalty, identification, and involvement. A person with high commitment tends to have a great desire to remain in the organization and has a very good presence as a form of loyalty to the organization. They also have a greater desire to develop organizational goals and adhere to organizational policies.

\section{METHOD}

Commitment is a state that cannot take and a condition that must be developed through feelings of involvement [1]. Next Steers Porter \& Lyman [2], commitment is a process in which a person is certified with his work. As the [1] author describes, commitment is a psychological condition that indicates a serious will to perform a specific action or job practice, and this is internalized within. Commitment in a person will make a person who has a great desire to do the work, both in the form of decisions themselves and in dealing with others. The good pressures that come from themselves and from others cannot be changed decisions and directions ofaction. To affirm the existence of members within an organization Stoner at.al [3], gives the definition of organization as a pattern of cooperation between two or more people who are bound in a structured way to achieve a particular set or set of goals. Purpose is a fundamental element in the organization, without a purpose, it is not unreasonable that an organization exists. It is something the organization must achieve, including its members.

\section{Result And Discussion}

\subsection{Discussion}

Commitment is a state that cannot take and a condition that must be developed through feelings of involvement [3] Next Steers Porter \& Lyman [4] commitment is a process in which a person is certified with his work. As Odiorme [5] describes, commitment is a psychological condition that indicates a serious will to perform a specific action or job practice, and this is internalized within. Commitment in a person will make a person who has a great desire to do the work, both in the form 
of decisions themselves and in dealing with others. The good pressures that come from themselves and from others cannot be changed decisions and directions of action.

School organization can be said as a social system whose purpose, whose members are able to provide the best service possible to achieve that goal. The service of members of the organization requires their commitment, namely the willingness to side with the organization, so that the organization can achieve its objectives.

To affirm the existence of members within an organization [5], gives the definition of organization as a pattern of cooperation between two or more people who are bound in a structured way to achieve a particular set or set of goals. Purpose is a fundamental element in the organization, without a purpose, it is not unreasonable that an organization exists. It is something the organization must achieve, including its members Further the [4] author states that the core of commitment is trust and intimacy. Trust is a proof of commitment, without trust a commitment will never exist. Trust is the fruit of commitment. The organization will give trust to its members because of the commitment of members to the organization. The existence of member commitment to organizational and organizational trust to members make the relationship both become harmonious, there is intimacy between members with members and between members and organizations. Commitment includes its orientation towards the organization in terms of loyalty, identification, and involvement. A person with a high level of commitment tends to have a great desire to remain in the organization and have an excellent presence as a manifestation of his loyalty to the organization. They also have a greater desire to develop organizational goals and adhere to organizational policies. According to Vijay Santhe as quoted Taliziduhu Ndraha [6] defines culture as: "The set of important assumption (often unstated) that members of community share in common".

Furthermore, Edgar Schein [7], states culture by: "a pattern of shared basic assumptions that the group learns as it solves its problems of external validation and internal integration, to be taught to new members as the correct way you perceive, think, and feel in relation to the problems. "Culture is difficult to define because it is abstract and has a multidimensional understanding with various aspects. Cultures are also dynamic and everchanging and become relatively stable over a short period of time. It takes time to change a culture especially in organizational culture. Culture is a social glue tool and produces closeness, so as to minimize differentiation within an organization. Culture in organizational context is called organizational culture. In the context of a company, termed corporate culture (corporate culture), and in educational institutions / schools is called the school culture (school culture). Certainly different from cultural studies of social anthropology or corporate organization in the organization of the school focus on behavior, thus raises the study of organizational behavior (organizational behavior).

In line with the above opinion, Schein [8] argues that: "An organization`s culture is a pattern of basic assumptions inverted or developed by given group as it learns to cope with its problem of external adaptation and internal integration that has worked well to be considered valid and to be taught to new members as the correct way to perceive, think and feel in relation to these problems. " Based on the above, it can be concluded that the definition of organizational 
culture is a set of assumptions or belief systems, values and norms developed and the organization devoted to the conduct of its members to address the problem of external adaptation and internal integration. Professional is defined as a work or activity undertaken by a person and becomes a living source of income that requires expertise, skill or skill that meets certain quality or norm standards and requires professional education as stated in Law number 14 Year 2005 on Teachers and Lecturers.

The term motivation comes from the Latin, i.e. movere which means to move. There are three aspects of motivation that can be identified. First, motivation describes an energy force that moves a person or causes them to behave in a particular activity. Second, this movement is directly aiming at a thing that is motivation that has a strong goal orientation (strong objectives). Third, help maintain morale all the time. The aspect of motivation that is expected to be a valuable factor in the work perspective system aims to understand human behavior in the work situation, so that aspect knows the most important factors and relates to personal behavior, situation and work environment; which further recognizes the existence of a work impulse, it is helpful to strengthen the working position [4] This is supported by McClelland's research, as cited by Newstrom [10] which focuses on motivational motivations to gain recognition (achievement), affiliation and power as seen in Table 1.

Table I: Result of Needs Assessment and Distribution SMK in Dairi High School Supervisors

\begin{tabular}{|l|l|}
\hline Motivation & Description \\
\hline Achievement & $\begin{array}{l}\text { The drive to reach the goal and } \\
\text { be in the front position }\end{array}$ \\
\hline Affiliation & $\begin{array}{l}\text { The urge to connect with others } \\
\text { effectively }\end{array}$ \\
\hline The Power & $\begin{array}{l}\text { affects others and controls the } \\
\text { situation }\end{array}$ \\
\hline
\end{tabular}

Associated with Maslow's hierarchy as a group of existences similar to a psychological group, the association is similar to a group of sense of belonging, social and compassion, and growth needs similar to that of selfesteem and self-actualization [6] Hakim, Adnan [11], conducts research entitled: Effects of Organizational Culture, Organizational Commitment to Performance: Study in the Hospital of the South Konawe District of Southeast Sulawesi. The relationship between organizational culture, organizational commitment and performance can be seen in Fi 1.

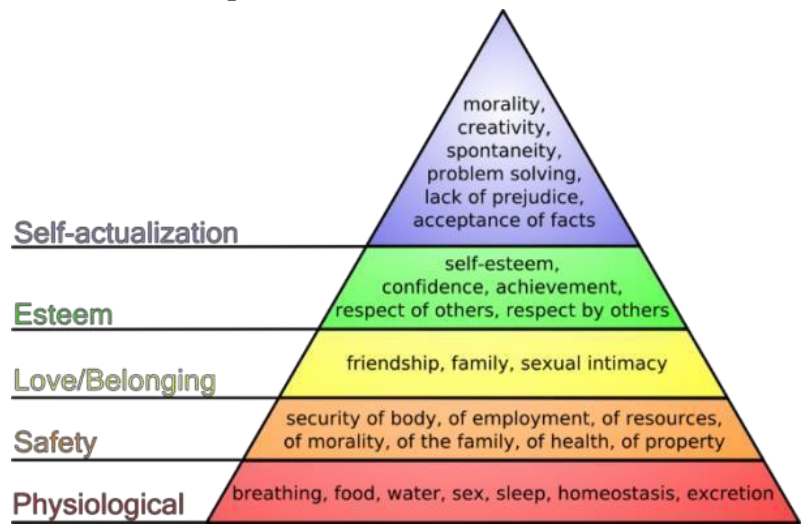




\section{A. Fig 1. Maslow Teori Hirakri}

The results of this study provide the following conclusions: (a) Organizational culture (innovation and risk taking, attention to detail, results orientation, people orientation, team orientation, aggressiveness and stability) has a significant impact in increasing organizational commitment (commitment continuance, normative commitment, affective commitment). (B) organizational culture has a significant influence in improving employee performance (quality, quantity, timeliness and cost effectiveness, monitoring needs and interpersonal impact). (C) The results of this study also found that organizational commitment has a significant effect on improving employee performance, and organizational commitment has an important role as a variable between organizational culture and employee performance. (D) The results indicate that, in order to improve the performance of employees in RSUD Konawe Selatan, South Sulawesi East Sulawesi Province needs to improve organizational culture and employee commitment to the organization

B. Result

The data have been collected from each of the variables studied, then tabulated in accordance with the purposes of the analysis in this study. The data descriptions include the size of the central tendency, such as the mean, the mean of the two middle data (median), the highest frequency score (mode), the size of the diffusion tendency, such as standard deviation, variance, range), lowest score (minimum), highest score (maximum), frequency distribution and histogram. Calculation and summary of descriptive analysis results can be seen inTable.2.

Table II. Result of Needs Assessment and Distribution SMK at Dairi

\begin{tabular}{|l|r|r|r|r|}
\hline \multirow{2}{*}{ Statistik } & \multicolumn{4}{|c|}{ Statistics } \\
\cline { 2 - 5 } & \multicolumn{1}{c|}{$\left(\mathrm{X}_{1}\right)$} & \multicolumn{1}{c|}{$\left(\mathrm{X}_{2}\right)$} & \multicolumn{1}{c|}{$\left(\mathrm{X}_{3}\right)$} & \multicolumn{1}{c|}{$\left(\mathrm{X}_{4}\right)$} \\
\hline Sample & \multicolumn{1}{c|}{208} & \multicolumn{1}{c|}{208} & \multicolumn{1}{c|}{208} & \multicolumn{1}{c|}{208} \\
\hline Mean & 138.99 & 110.23 & 136.99 & 101.66 \\
\hline Modain & 141.00 & 112.00 & 140.00 & 103.00 \\
\hline Std. Deviasi & 146.00 & 125.00 & 134.00 & 111.00 \\
\hline Variance & 16.42 & 15.82 & 16.46712 & 10.80 \\
\hline Ranger & 969.75 & 250.37 & 271.17 & 116.54 \\
\hline Minimum & 82.00 & 79.00 & 87.00 & 56.00 \\
\hline Maximum & 172.00 & 64.00 & 81.00 & 67.00 \\
\hline Total & 39474.00 & 31305.00 & 38904.00 & 28871.00 \\
\hline
\end{tabular}

$\mathrm{X} 1$ = Organisation Culture X2 = Pedagogic Comptency X3 = Work Motivation $\mathrm{X} 4$ = Organisation Commitment

In detail the results of descriptive analysis associated with the answer statement selected respondents can be viewed based on a summary analysis of the frequency distribution of group data presented with Table. 2 . 
Based on Table. 2 shows that the spread of the frequency of teacher commitment organization variable is distributed with the distribution that tend to dominant in the middle. It is indicated that, the commitment of SMK teacher organization in Dairi Regency is still quite good. Distribution of value distribution of teacher commitment organizational variable scores can be seen in Figure 2 the following histogram.

1) Organizational Culture

Operationally the concept of culture is rather difficult to define because it is abstract and has a multidimensional understanding with various points of view and aspects. Therefore, organizational culture is a norm that is believed can be used as a reference to behave in the organization so as to facilitate the achievement of organizational goalseffectively. The description of the above analysis can be seen in the summary of the grouping of data with the three categories that can be seen in the Table.2.

2) Pedagogic Competencies

A teacher is said to have pedagogical competence if there are several indicators as follows: (1) mastery of the characteristics of students from the physical, moral, social, cultural, emotional and intellectual aspects, (2) mastery of learning theories and principles of educational learning, 3) able to develop curriculum related to the field of developing development, (4) organize educational development activities, (5) utilize information and communication technology for the purpose of organizing educational development activities, (6) facilitate the development of potential students to actualize various potentials owned, (7) communicates effectively, empathically, and courteously with all students, (8) conducts assessment and evaluation of learning process and outcomes, utilizes assessment and evaluation results for learning purposes, (9) takes reflective action to improve learning quality. These nine indicators are translated into 36 items of statements contained in the instrument. After the composite score resulted in the lowest score of 64.00 and the highest score 143.00 average count (Mean) 110,23, median (Me) 112,00, mode (125.00) variance 250,37, deviation standard (standard deviation) 15.82. Thus the distribution of data of pedagogic competence variables can be seen with Table. 3 . The table shows that the spread of frequency of pedagogical competence variable data tends to form a normal / symmetric curve. This is shown by the median value and the near-average mode.

3) Work Motivation

An overview of the answers given by the respondents having the characteristics as described before can be explained through the results of descriptive statistical analysis. After the scores are composed then the lowest score is 81.00., the highest score is 168.00 , , the mean count is 136.99 , median (Me) 140.00 , mode 134.00 variance (variance) 271.17 , standard deviation (standard deviation) 16.46. Based on the average score count gives an overview of the answers in which respondents chose the answer with a score of 5 . This indicates that the motivation of the teacher of SMK with the choice of answers strongly agree to carry out activities derived from encouragement from within, external encouragement, as well as rewards that is sufficient. When assessed on the basis of the minimum, maximum, average and value scores of the obtained variance values, it is understood that the variance score is above the maximum value. Thus, the tendency that the choice of answers given by respondents is very diverse. Nevertheless, the average of respondents chose the answer between the choice 
of answers agreed, and less agree. The result of descriptive analysis of teacher motivation variable data can be seen in Table. 2

\section{Conclusion}

- Direct Influence Between Organizational Cultures Against Work Motivation of Vocational Teachers. Based on the results of the first hypothesis testing that has been done previously proven empirically that the organizational culture owned by SMK teachers in Dairi Regency have a direct positive and significant effect on work motivation in carrying out educational and teaching tasks in school.

- $\quad$ Direct Influence Between Organizational Culture Agreements on Vocational Teacher Organization Commitment. Based on the results of the second hypothesis testing that has been done previously proven empirically that the organizational culture of teachers in Dairi Regency have a positive and significant impact on organizational commitment.

- Direct Influence Between Pedagogic Competences Against Work Motivation of Vocational Teachers. Based on the results of the third hypothesis testing that has been done previously proven empirically that pedagogic competence possessed by teacher in Dairi Regency have positive and significant effect to work motivation of teacher.Direct Influence Between Pedagogic Competence Against Vocational Teacher Organization Commitment

- $\quad$ Based on the results of the fourth hypothesis testing states that the pedagogical competence of SMK teachers in Dairi Regency has a positive and significant impact on organizational commitment.

- Direct Influence Between Work Motivations Against Vocational Teacher Organization Commitment.

Based on the results of the analysis that has been done shows that the motivation of work directly and significantly affect the commitment of teacher organizations. The results of this analysis firmly prove that the fifth hypothesis of this study has been proven empirically. Therefore, to obtain the functional value of the results of this study, it is necessary to make an appropriate interpretation, appropriate and proportional to the variable work motivation and organizational commitment.

\section{References}

Colquitt, Jason A., Jeffery A. LePine., \& Wesson, Michael J. 2009. Organizational Behavior. New York: McGraw-Hill International

Companies

Farrell, D., \& Stamm, C. 1988. Meta-Analysis of the Correlates of Employee Absence. Human Relations.

Gurney, Philip. 2007. Five Factors for Effective Teaching. New Zealand Journal of Teacher's Work, Volume 4, Issue 2, 89-98.

Diakses dari internet tanggal 29 Oktober 2017.

McKenna, Eugene \& Nic Beech. 2008. Human Resource Management: a Concise Analysis. New York: Prentice-Hall.

Stoner, James A,. R. Edward Freeman \& Daniel R. Gilbert. 1995. Management. Englewood Cliffs: Prentice-Hall Inc. 
Stout, Kenneth \& Walker, Alan. 1995. Teams, Teamwork and Teambuilding. The Managers Guide to Team in Organizations.

Singapore: Prentice-Hall Company.

Wibowo., H.,A., 2009. Pengaruh Independensi Auditor, Komitmen Organisasi, Gaya Kepemimpinan dan Pemahaman Good

Governance Terhadap Kinerja Auditor. Diterbitkan DalamJurnal UNS.

Syauta, Jack Henry. 2012. The Influence of Organizational Culture, Organizational Commitment to Job Satisfaction and Employee Performance (Study at Municipal Waterworks of Jayapura, Papua Indonesia). Dalam International Journal of Business and Management Invention ISSN (Online): 2319 - 8028, ISSN (Print): 2319 - 801X www.ijbmi.org Volume 1Issue 1 I|| December. 2012 ||| PP.69-76. (http://ijbmi.org/papers/Vol(1)1/H116976.pdf).

Sergiovanni, T. J., and Carver, F.D. 1999. The School Executive: A Theory of Row. Publishers. Administration. ( $2^{\text {nd }}$ Ed). New York: Harper and

Hoy, Wayne K. \& Miskel, Cecil G. 2001. Educational Administration Theory, Research, and Practice $6^{\text {th }}$ ed., International

Edition, Singapore: McGraw-Hill Co.

Arikunto, Suharsimi. 2006. Prosedur Penelitian: Suatu Pendekatan Praktik. Jakarta: RinekaCipta.

Armstrong, Michael. 1999. Manajemen Sumber Daya Manusia; Judul Asli: A Handbook of Human Resources Management.

Diterjemahan kedalam Bahasa Indonesia oleh Sofyan Cikrat dan Haryanto. Jakarta: Elex Media Komputindo. 